\title{
都市高速道路交通安全対策立案へのファジィ理論の応用
}

\section{AN APPLICATION OF FUZZY SET THEORY TO TRAFFIC SAFETY PLANNING ON URBAN EXPRESSWAY}

\author{
秋山孝正* ·邵 春福**・内田敬*** ·佐佐木 綱**** \\ By Takamasa AKIYAMA, Chun-Fu Shao, Takashi UCHIDA and Tsuna SASAKI
}

\begin{abstract}
Traffic safety planning on urban expressway becomes important problem. Three methods to obtain better combination of countermeasures within certain budget were already proposed. They all have mathematical crisp formulation. On the contrary, fuzziness in actual economical evaluation should be considered for advanced traffic safety planning. Some application of fuzzy set theory will be shown in this study. Fuzzy budget constraints are used for modification of Incremental Benefit-Cost Analysis and Dynamic Programming Approach. For further investigation, fuzzy benefit coefficients are also discussed to obtain and display more actual alternatives.

Keywords : fuzzy budget constraints, urban expressway, traffic safety planning
\end{abstract}

\section{1.はじめに}

都市内交通の円滑・安全・快適な輸送を目指す都市高 速道路は一般道路に対して道路構造上からも交通の安全 性は高いといえる.したがって道路交通全体の安全確保 という意味では一般道路を主とした広域的交通安全施策 を検討することは必要不可欠である1”.

しかし本来, 交通安全対策は人身事故の危険, 円滑交 通阻害の側面から高速道路交通計画においてもなお検討 すべき課題であり，また混合交通ではない状況下での一 般道路とは異なる安全施策の必要性もあり，この問題に 特に注目し検討することは有意義である.

また都市高速道路においては，高速走行を基本とする 道路構造となっていること, 交通安全施設の設置が基本 となること, 安全対策立案では路線単位の個別対策案を 考えこれらを特定予算制約の中で実行するという計画の 枠組みをもつことなどから，問題の具体的な定式化にお

* 正会員 工博 京都大学講師 工学部交通土木工学教室 ( ₹606 京都市左京区吉田本町)

** 学生会員 工修 京都大学大学院 工学研究科交通土木 工学専攻 (同上)

*** 正会員 工修 京都大学助手 工学部交通土木工学教室 (同上)

**** 正会員 工博 京都大学教授 工学部交通土木工学教室 (同上)
いては, 数理計画法の応用が提案されてきた.すなわち 効率的加有効な対策案とする手順の定式化と求解につ いて考察するものであり，いくつかの方法の比較検討が なされてきた。

こうした数理計画的定式化を採用する場合，現実的に は, (1)都市高速道路における交通安全対策立案に際して, 運営上，交通安全対策経費を独立して計上していないこ と，(2)各安全施策を実施した場合に生じる交通事故の軽 減によって得られる経済的効果（便益）が必ずしも計量 的確定值として予測することが難しいといったことか ら, 現実性のある実行可能な計画立案を考える場合には, これらの不確定的な状況を考慮に入れた検討を行う必要 がある。

そこで本研究では，まず都市高速道路における個別の 交通安全対策から構成される代替案作成問題とその従来 の解法について検討する，次に個別の安全対策の組合せ として安全対策の代替案を作成する方法について検討結 果を整理する.また都市高速道路における実際的な適用 について検討する.さらに安全対策の立案方法に対して， ファジィ性を考慮した方法論的改良について検討するこ ととした.ファジィ化により, 従来の数理計画的な交通 安全対策案導出手順の合理性と各方法の利点を拡張し, より一般的に利用可能とすることを目指すものである. 


\section{2. 都市高速道路の安全対策立案}

\section{（1）安全対策立案問題と従来の解法}

従来の研究にも示されるように，ここで注目する問題 は, 都市高速道路の交通安全対策代替案の構成要素であ る各地点の詳細な安全施設設置計画の内容と，その個別 計画実施による費用・効果が貨幣価值で計上されている とき,これらの組合せとして高速道路路線全体の交通安 全対策案を作成するものである。

つまり計画目標は「交通安全対策に要する費用上限に 対し，この範囲内で最も効果的な代替案を求めること」 である. 同種の問題については，アメリカのFHWA (Federal Highway Administration) 報告書に具体的検 討結果が示されており ${ }^{21}$ ，またこれらの計算方法に関し て基礎的整理が行われている.

まず本研究で取り扱う都市高速道路における交通安全 対策の概要を検討する.

都市高速道路では各種原因の交通事故が発生し，また 偶発的事象ではあるが, 道路構造上の問題や過大な交通 量が事故の原因となる場合も多く，事故多発場所を知る ことは可能である.このことから曲線部, 合流部, 分岐 部での交通安全対策が考えられる。具体的には表一1に 示すように，それぞれの対策案で個々の安全施設を何か 所に設置するかが基準となっている3.

たとえば環状線の第 1 案（表中の I-1）は，具体的に は, 曲線部で赤色点滅灯と注意標識示をそれぞれ 10 か 所 $\left(\mathrm{C}_{1} \times 10, \mathrm{C}_{3} \times 10\right)$, 分岐部で路面標示を 20 か所 $\left(\mathrm{D}_{1}\right.$ $\times 20)$ ，合流部で路面標示を 20 か所 $\left(G_{1} \times 20\right)$ にそれ ぞれ設置するものである。したがってこの費用は，これ らの個別施設の経費の総額で 1820 万円である。 また便 益はこの対策案の実施効果を予測計上したものである ${ }^{4}$.

費用・便益に関する厳密不変な方法が存在すれば，当 然これらの值は確定的に決定される。しかし実際には現 実的制約，計測可能性なぞから確定值を設定しにくいた め, 特定の問題に限定し (ここでは施設設置)，また以 下で行うような数理計画的な解法を用いる差異には 1 つ の最確値としてこれらを用いる。

ここで考慮すべき問題は具体的には表中に挙げられて いるそれぞれの対策案から路線ごとに高々 1 案を選択 し，ある安全対策予算内で適当な対策案を抽出してこの 組合せとして代替案を作成するものである.

\section{（2）最適安全対策の導出方法}

さきに示した問題解決において，単純な便益・費用の 比から検討する方法のほかに数学的アルゴリズムとして 記述可能な方法として以下のような手法が提案されてい る. (1)増分費用便益分析による方法 (Incremental Benefit-Cost Analysis)，(2)ダイナミックプログラミング
表一1 個別交通安全対策案の例

\begin{tabular}{|c|c|c|c|c|c|}
\hline NO & 路 & 䎹 & 対策案の内容 & 費用 & 便 益 \\
\hline (1) & I & $\begin{array}{l}1 \\
2 \\
3\end{array}$ & $\begin{array}{l}C_{1} \times 10, C_{3} \times 10, D_{1} \times 20, G_{1} \times 20 \\
C_{1} \times 10, C_{2} \times 10, C_{3} \times 10, D_{2} \times 20, \\
G_{1} \times 200 \\
C_{2} \times 10, C_{3} \times 10, C_{5} \times 6, D_{1} \times 20\end{array}$ & $\begin{array}{l}1820 \\
3340 \\
2440\end{array}$ & $\begin{array}{l}19200 \\
21700 \\
25600\end{array}$ \\
\hline (4) & II & $\frac{1}{2}$ & $\begin{array}{l}C_{3} \times 10, D_{1} \times 20, D_{2} \times 20, G_{2} \times 20 \\
C_{2} \times 4, D_{1} \times 20 . D_{2} \times 10\end{array}$ & $\begin{array}{r}1420 \\
502\end{array}$ & $\begin{array}{r}13300 \\
6400\end{array}$ \\
\hline (6) & III & $\begin{array}{l}1 \\
2 \\
3\end{array}$ & $\begin{array}{l}C_{1} \times 8, C_{4} \times 10, D_{1} \times 10, G_{1} \times 10, \\
G_{2} \times 10 \\
C_{1} \times 2, C_{5} \times 2, G_{1} \times 10, G_{2} \times 20 \\
C_{2} \times 10, C_{3} \times 10, G_{1} \times 20, G_{2} \times 40\end{array}$ & $\begin{array}{r}1090 \\
930 \\
2340\end{array}$ & $\begin{array}{r}10520 \\
6750 \\
22520\end{array}$ \\
\hline (1) & IV & $\begin{array}{l}1 \\
2 \\
3\end{array}$ & $\begin{array}{l}D_{1} \times 40, D_{2} \times 20 \\
C_{1} \times 10, D_{1} \times 20, D_{2} \times 10, G_{2} \times 10 \\
C_{1} \times 10, C_{3} \times 10, C_{4} \times 10, D_{1} \times 40, \\
D_{2} \times 10, G_{1} \times 10, G_{2} \times 20\end{array}$ & $\begin{array}{r}380 \\
1390 \\
2410\end{array}$ & $\begin{array}{r}3000 \\
12300 \\
24710\end{array}$ \\
\hline (12) & V & $\begin{array}{l}1 \\
2 \\
3\end{array}$ & $\begin{array}{l}C_{1} \times 10, D_{1} \times 40, G_{1} \times 20 \\
C_{2} \times 10, C_{3} \times 10, C_{5} \times 6, D_{2} \times 10, \\
G_{1} \times 10 \\
C_{2} \times 10, C_{4} \times 10, G_{1} \times 10\end{array}$ & $\begin{array}{r}1180 \\
2540 \\
840\end{array}$ & $\begin{array}{r}7200 \\
24890 \\
5980\end{array}$ \\
\hline (15) & VI & $\begin{array}{l}1 \\
2\end{array}$ & $\begin{array}{l}C_{1} \times 10, C_{2} \times 10, C_{5} \times 10, D_{1} \times 20, \\
D_{2} \times 20, G_{2} \times 20 \\
C_{1} \times 10, C_{5} \times 6, D_{1} \times 40, D_{2} \times 40, \\
G_{2} \times 10 \\
C_{3} \times 10, C_{4} \times 10, D_{2} \times 20, G_{1} \times 10, \\
G_{2} \times 10\end{array}$ & $\begin{array}{l}4000 \\
2740 \\
1220\end{array}$ & $\begin{array}{l}40400 \\
24100 \\
11590\end{array}$ \\
\hline (18) & VII & $\frac{1}{2}$ & $\begin{array}{l}C_{3} \times 10, D_{1} \times 10, G_{1} \times 10 \\
C_{5} \times 2, D_{2} \times 20, G_{1} \times 20, G_{2} \times 20\end{array}$ & $\begin{array}{r}760 \\
1020\end{array}$ & $\begin{array}{l}7300 \\
9420\end{array}$ \\
\hline \multicolumn{6}{|c|}{ [note] } \\
\hline
\end{tabular}

による方法 (Dynamic Programming)，(3)整数計画法に よる方法 (Integer Programming)。これらは，さきの FHWA の研究に基づき，これまでに著者らが紹介して いるものであり，その詳細な演算手順についてはここで は割愛する ${ }^{4) ~ 6) . ~}$

さきの表一1に示した安全対策案集合に対して，計画 予算制約として，7900万円を設定した場合を例とす る.この場合の便益最大という点からの組合せ最適解は 唯一であり, [採択案：I-3, II-2, IV-3, V-2, 便益： 81600 万円/費用：7892 万円] である. 当然ながら，(1) 〜3)のいずれによってもこの解を得ることができる。し たがって各計算法の特徵は計算の厳密性と効率性, 計算 結果の表現形式等によって比較を行うことになる.

a）増分便益費用分析による方法

この方法は, 各対策案相互の関係について一方の対策 案を選択するために必要な費用増分 $(\Delta C)$ に対して，に゙ の程度の便益増分 $(\Delta B)$ が見込まれるかという点から開 発されたアルゴリズムである5!.

この方法における表現上の利点は，演算結果から得ら れる増分便益費用比について表一2に示すようなワーク シートが得られることである.この表は增分便益費用比 $\left(R_{i j}=\Delta B / \Delta C\right)$ の順位により作成されており，代替 的対策案の選択されるべき順序が容易に把握でき, また この表は一意的に決定される.したがって当該予算額が 変化したような場合にも, 総費用欄の値を用いて実行可 能性（予算制約の範囲内での）を検討することで，新た 
表一2 増分便益費用分析のワークシート

\begin{tabular}{|c|c|c|c|c|c|c|}
\hline $\begin{array}{l}\text { 竓策 } \\
\text { 番号 }\end{array}$ & 増䨘用 & 増畕 & $R_{i j}$ & 総費用 & 総便益 & 採 \\
\hline $\begin{array}{l}\text { II }-2 \\
\text { I }-1 \\
\text { I }-3 \\
\text { IV }-3 \\
\text { VI - } \\
\text { V }-2 \\
\text { III }-1 \\
\text { VII - }\end{array}$ & $\begin{array}{r}502 \\
1820 \\
620 \\
2410 \\
4000 \\
2540 \\
1090 \\
760\end{array}$ & $\begin{array}{r}6400 \\
19200 \\
6400 \\
24710 \\
24890 \\
10520 \\
7300 \\
12000\end{array}$ & $\begin{array}{r}\text { 12. } 75 \\
\text { 10. } 55 \\
\text { 10. } 32 \\
\text { 10. } 25 \\
\text { 10. } 10 \\
\text { 9. } 80 \\
\text { 9. } 65 \\
\text { 9. } 60\end{array}$ & $\begin{array}{r}502 \\
2322 \\
2942 \\
5352 \\
9352 \\
7892 \\
8982 \\
8652\end{array}$ & $\begin{array}{r}6400 \\
25600 \\
32000 \\
56710 \\
97110 \\
81600 \\
92120 \\
88900\end{array}$ & $\begin{array}{l}* \\
* \\
*\end{array}$ \\
\hline
\end{tabular}

(単位：万円）

な対策案の組合せを知ることが可能である.

b) DPによる方法

この方法の定式化の基本的部分は次のようである.

$$
f_{n}\left(S_{n}\right)=\max \left\{r_{n}\left(S_{n}, d_{n}\right)+f_{n-1}\left(S_{n-1}\right)\right\} \text {. }
$$

$S_{n-1}=S_{n}-C\left(d_{n}\right)$

ここに, $S_{n}: n$ ステップにおける総費用, $d_{n}: n$ ステッ プでの選択対策案, $f_{n}\left(S_{n}\right): n$ ステップにおける最大総 便益， $r_{n}\left(S_{n}, d_{n}\right)$ : 総費用 $S_{n}$ で $d_{n}$ 案を採用した際の便 益, $C\left(d_{n}\right): d_{n}$ 案実施に要する費用

つまり，各ステップ（本例では各路線を順に考慮する ことに対応する）において，対策案 $d_{n}$ を採用していき， 順次加算されて得られる総便益を最大化しようとするも のである.

この方法では，定式化を行ううえで計画における増分 単位費用 (increment of cost) を考えることができる. つまり「個別安全対策が複数同時に実施されて初めて効 果を与える場合」，「投資予算が一定単位額で計上されて いる場合」に対応し，いずれの場合も連続的な投資額に はならないからである。

本問題では個々の対策案が最小 10 万円の単位で表示 されており，増分単位費用を 10 万円として計算すれば, 当然最大便益解 (81 600 万円) と一致する.また増分単 位費用の值を大きくしていけば，単調ではないが全般的 傾向として計算結果の便益額は小さい値の組合せとなる.

たとえば単位費用 100 万円の場合には最適解から $2.3 \%$ の便益減少がみられる。この程度の便益減少が現 実的な解の良否に関係するか否かは実際的な（上記 $2 つ$ の理由なよ゙から）検討の必要がある。

また計算上の問題では，一般的に小さな幅で計算を行 うことは当然その各ステップの演算回数を増加させるこ とになり，演算に要する時間は増大することは明らかで ある、つまり計算効率からは増分単位費用を大きくとる ことが望ましく，逆に解の㛜密性からいえばこれを小さ くする必要がある。

したがってこの方法においては，いかなる「増分単位 費用額」を用いるかを計画段階で考慮できる点が重要な 特徵となっている. c）整数計画法による解法

この方法は, いわゆる 0-1 計算問題として定式化した ものであり,計算アルゴリズムとしての複雑さはあるが, 数式的表現は明解である.すなわち, 予算制約 (式 (4)) と路線の制約（式（5)：各路線で高々 1 案を採用する こと）のもとで総便益を最大化するものである.

$$
\begin{aligned}
& \max \sum_{i} \sum_{j} b_{i j} \cdot x_{i j} \quad \begin{array}{l}
j \in J \text { : 路線集合 } \\
i \in N \text { : 対策案集合 }
\end{array} \\
& \text { s.t. } \\
& b_{i j} \text { : 対策実施便益 } \\
& \sum \sum c_{i j} \cdot x_{i j} \leqq B \quad c_{i j} \text { : 対策案実施費用 } \\
& B \text { : 予算制約 } \\
& \sum_{k} x^{k} \leqq 1 \\
& k \in G: \text { 各路線での実行 } \\
& \text { 可能案の数 } \\
& x=0,1
\end{aligned}
$$

この方法における特徵は次のような点である.

(1) 組合せ最適化問題として基本的な定式化がなされ ているので, 当然数学的に厳密な最適解を求めることが できる. 具体的には通常の整数計画法の解法手順を用い ることができる(必ずしも一般的に容易ではないが,パッ ケージプログラムなどもある).

(2) 定式化が数理的に簡潔であるので，制約条件，便 益額あるいはその他の計画条件の変化は, 定式化の若干 の変更で対応することができる(本例のような場合には， 計画実施のための優先路線を考慮した場合なよ゙が挙げら れる).

\section{（3）安全対策立案とファジィ性の考慮}

以上のような数理計画的方法は計算実行上のいくつか の特徵をもち，それぞれ組合せ最適解を得る方法として 有効であることが紹介されている．したがって安全対策 立案時の計画条件と合致する方法を用いることで, 各方 法の現実的有効性が見出されるものと思われる.

また, 表一1 の值がきわめて正確に計測され，またこ の数量を厳格に用いた計画の場合には，上記のおのおの の最適解が現実の安全対策実施上も確実な効果を発揮す ると考えられる.

しかしこれらの方法を都市高速道路の交通安全対策立 案に一層適切に応用するためには, 現実計画実施に伴っ て生じる不確定な要因を考慮することが重要となると考 えられる。ここでは主要なものとして以下の 2 点を考え ることにした。

(1) 都市高速道路の交通安全対策に用いることのでき る経費は，普通「維持管理費」等の関連経費に内包され て考えられていることが多い。したがって安全対策への 予算は概略的には計上することができるが確定的には難 しい．実際の運営を考慮しても計画変更に対する柔軟性 をもたせた方法を用いることは現実的である.

(2) 経済効率から最適な安全対策案を立案する場合 に，各対策案の費用・便益が中心的な資料となるが，実 
際には定量的,画一的に計測が困難な要因も含まれる(た とえば快適性の向上など)。したがって特に予測される 便益值等に若干の判断の幅を含めて検討することが現㬰 的である。

以下では，このような検討結果に基づき従来方法の ファジィ理論を用いた修正を行うことにする.

\section{3. ファジィ制約を用いた代替案立案計画}

\section{（1）ファジィ数理計画法}

まず一般的なファジィ数理計画の方法について述べ る.

ファジィ最適化の概念は 1970 年に R. E. Bellman と L.A. Zadeh がファジィ環境における意思決定として, 代替案集合 $X$ 上にファジィ目標(fuzzy goal)とファジィ 制約 (fuzzy constraints) が与えられた際の検討を行っ たものが端緒である7!.ここでファジィ目標 $G$ とファ ジィ制約 $C$ は，メンバシップ関数 $\mu_{G}, \mu_{C}$ によって定義 される代替案の集合 $X$ 上のファジィ集合である.

このときファジィ目標とファジィ制約を統合した決定 集合を定義する必要がある. Bellman とZ Zadehは，ファ ジィ目標 $G$ とファジィ制約 $C$ を同時に満たすことを考 慮して，ファジィ決定 (fuzzy decision) $D$ を，ファジィ 目標 $G$ とファジィ制約 $C$ との共通集合と定義した。

すなわちファジィ決定 $D$ は,

$D=G \cap C$

であると定義され，そのメンバシップ関数は,

$$
\mu_{D}(x)=\mu_{0}(x) \wedge \mu_{c}(x)
$$

である。一般に複数個のファジィ制約が存在する場合へ の拡張は容易に行うことができる. $G_{1}, G_{2}, \cdots, G_{n}$ を ファジィ目標とし， $C_{1}, C_{2}, \cdots, C_{m}$ をファジィ制約と すればファジィ決定 $D$ は,

$$
D=G_{1} \cap G_{2} \cap \cdots \cap G_{n} \cap C_{1} \cap C_{2} \cap \cdots \cap C_{m}
$$

と定義され,このメンバシップ関数は以下のようである. すなわち目標と制約の共通の満足程度をメンバシップ関 数として表現したものである.

$$
\begin{aligned}
\mu_{D}(x) & =\min _{\substack{1 \leq i \leq n \\
1 \leq j \leq m}}\left(\mu_{G_{i}}(x), \mu_{c_{j}}(x)\right) \\
& =\min \left(\mu_{G_{1}}(x), \cdots, \mu_{G_{n}}(x), \mu_{c_{1}}(x), \cdots, \mu_{c_{m}}(x)\right)
\end{aligned}
$$

ファジィ決定 $D$ における意思決定としては， $D$ に帰 属する度合を最大にするような $x$ を選ぶという最大化 決定が提案されている．すなわち，

$$
\mu_{D}\left(x^{*}\right)=\max _{x \in X} \mu_{D}(x) \text {. }
$$

となるような $x^{*}$ を求めるものである．ここで，このよ うな $x^{*}$ は存在しない場合もあれば，無数に存在する場 合もある．またこの最大化決定のほかに「凸ファジィ決 定」や「積ファジィ決定」などが提案されている.

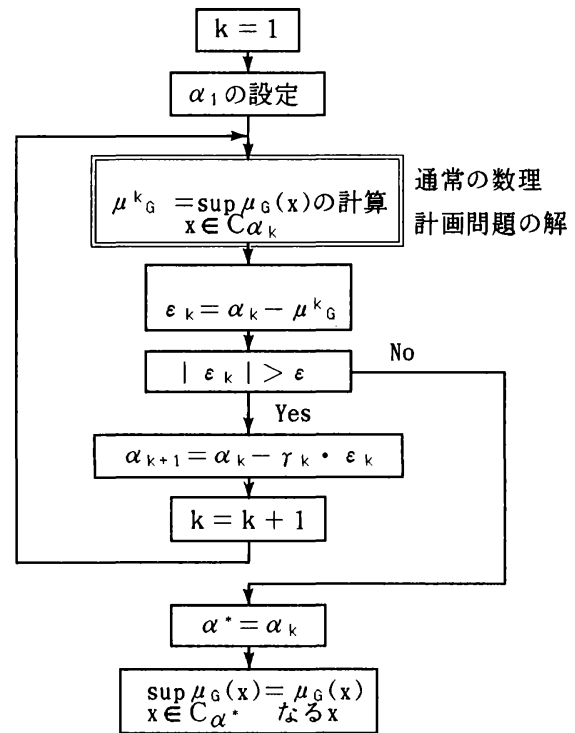

図一1 ファジィ数理計画問題の解法手順

[ファジィ数理計画法の解法］

さきに述べた最大化問題は， $\alpha$-レベル集合を用いて 次の最大化問題に転化できる ${ }^{8)}$.すなわち,

$$
\sup _{x} \mu_{D}(x)=\sup _{\alpha \in[0,1]}\left[\alpha \wedge \sup _{x \in C \alpha} \mu_{G}(x)\right]
$$

この式は $\alpha$ レベルごとの各問題における解のうち, 最大のものを求めることを示している.このファジィ数 理計画法の解法は一般に図一1に示すような， $\alpha$ カット を用いて反復計算で求めることができる $(\varepsilon$ ：収束判断 基準).

本図よりわかるように，このアルゴリズムには「通常 の数理計画問題」の解法をプログラム中に含んでいる. したがって，このアルゴリズムを用いることで，通常の 数理計画問題はすべてファジィな意思決定問題に拡張て きることがわかる。

このフローからわかるように一般に目的関数のメンバ シップ関数值 $\left(\mu_{G}\right)$ と制約条件のメンバシップ関数值 $\left(\mu_{c}\right)$ の一致性から解を求めることができる.したがって, 特 定の収束判定基準を満たすものを解とするものである.

本研究では，このアルゴリズムを利用したファジィ数 理計画問題として各解法を考えるために，ファジィ目標 $\mu_{G}$ を定義する．ここでは，いずれの解法の場合も予算 の上限制約をもつ便益の最大化決定問題であることか ら，次のように定義した。

$$
\mu_{G}(x)=Z_{\jmath}(x) / Z^{*}(x)
$$

ここに, $Z_{\circlearrowleft}(x): x \in C_{\alpha}$ の際の数理最適解, $Z^{*}(x):$ 制 約を最大限 $\left(\mu_{c}(x)=0\right)$ とした場合の数理最適解

またファジィ制約を示す $\mu_{c}$ は次のように定義される. 


$$
\mu_{c}(b)=\left\{\begin{array}{cr}
1 & b \leqq B^{-} \\
\psi(b) & B^{-} \leqq b \leqq B^{+} \\
0 & b \geqq B^{+}
\end{array}\right.
$$

ここに, $B^{-}$: 設定制約值, $B^{+}$: 制約可能最大限度, $\psi(b)$ : 単調減少関数

\section{（2）ファジィ制約をもつ增分便益費用分析}

\section{a) 計算手順の概要}

ここで検討する「ファジィ制約」は計画段階において 予算面の余裕をもつ計画を行うことに相当する．もし予 算面で従来のクリスプ制約を用いて計画立案を行う場合 には，これを若干でも超過する代替案は選択可能性がな い.これに対してファジィ制約を付加することによって, 余裕を見込んだ計画立案を試みるものである ${ }^{9 !}$.

すでにみたように増分便益費用分析においては，予算 制約は，最終的に増分便益費用比の順が決定され（既出 のワークシートに相当)，この組合せ選択時に考慮され る.したがって予算の変化に対しては無理なく対忘でき る方法であるといえる。したがって，ファジィ費用制約 の場合にも従来手順を組み込んだ同様のファジィ数理計 画の解法手順を用いることができる.

ただし本研究での代替案作成問題は組合せ最適化問題 であるから，解は連続的には変化せず段階的な変化をす る.したがって目的関数と制約条件のメンバシップ関数 はそれぞれ階段関数と連続関数となり「ファジィ最適化 問題」は必ずしも交点をもつとは限らない( ${ }^{91,101}$.

この状況を制約条件と目的関数のメンバシップ関数の 関係として示す．いずれの場合においても，予算制約值 $b$ の増加に伴って $\mu_{c}$ は減少， $\mu_{G}$ は増加する傾向をもつ. 図一2のような両関数に交点が存在する場合はこれが解 となり問題がないが，各関数が交点をもたない図一3の ような場合には，定義に従えば図中の $P\left(s, \mu_{c}(s)\right)$ が ファジィ最適決定点である，すなわち，式 (11) を満た す最大化決定がなされたということである.

これを計算アルゴリズムとして考慮する必要がある が，本図からもわかるように，このときの両メンバシッ プ関数値の関係は必ず,

$$
\mu_{\sigma}(s) \geqq \mu_{c}(s)
$$

である．この性質を利用して，ファジィ最適化の演算ア ルゴリズムを図一4に示すようなものとした。

簡単にそのメカニズムを考えると，制約条件のメンバ シップ関数を考え $\alpha$ カット集合を $\alpha=1$ から（したがっ て $\mu_{G}=1$ から）計算を始め， $\alpha$ を順次微少なステップ幅 で減少させ，ある值に至ったとき，当該ステップにおい て, 初めて $\mu_{G}(s) \geqq \mu_{c}(s)$ の条件が満たされなくなった場 合 $\left(つ ま り \mu_{G}(s)<\mu_{c}(s)\right)$ に， その直前ステップの目的 関数值を求めるというものである.

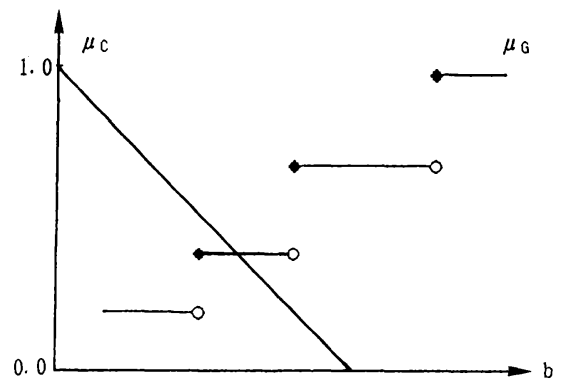

図一2 ファジィ制約（ケース1）

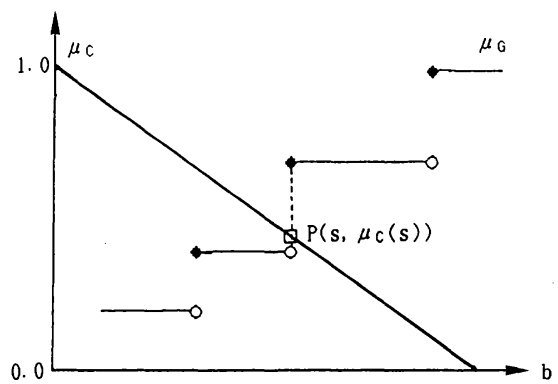

図一3 ファジィ制約（ケース 2 )

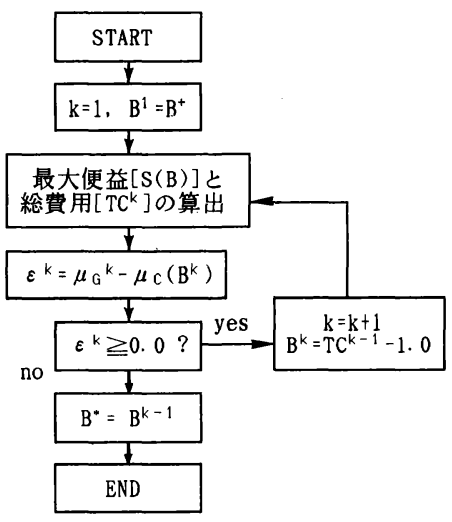

図一4 ファジィ増分便益費用分析の解法手順

b）計算結果とその検討

ここでは，予算制約条件に対して，変化傾向の異なる 2 種類のメンバシップ関数のタイプを考えた.

図一5 は線形に変化するメンバシップ関数であり, 図 一6は $Z$-関数之よばれる非線形の変化をするものであ る.ここで， $B^{-}$は当該問題の初期予算額（したがって, 7900 万円）とし，それぞれの関数タイプに対して制約 条件の $B^{+}$を変化させて最適解を求めた場合の総費用と 総便益を表一3に示す.

制約条件の上限 $\left(B^{+}\right)$を大きくすると当然のことなが ら得られる解も大きくなる．また関数形 $(\psi(x))$ による 差異を比較すると, $\mu_{c}>0.5$ の部分（変曲点より $B$ が 小の部分) では, $Z$ 関数の偏曲により, 同一満足度であっ 


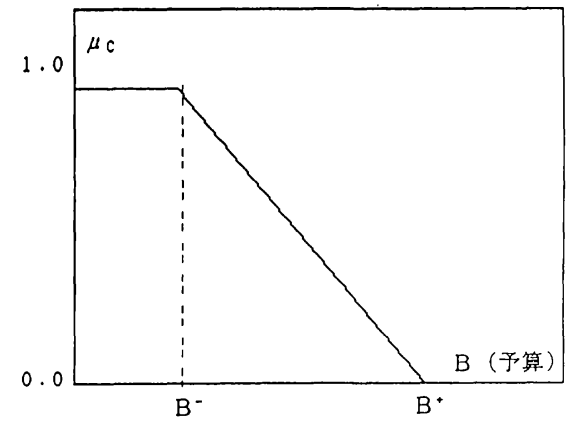

図一5 線形の費用制約条件

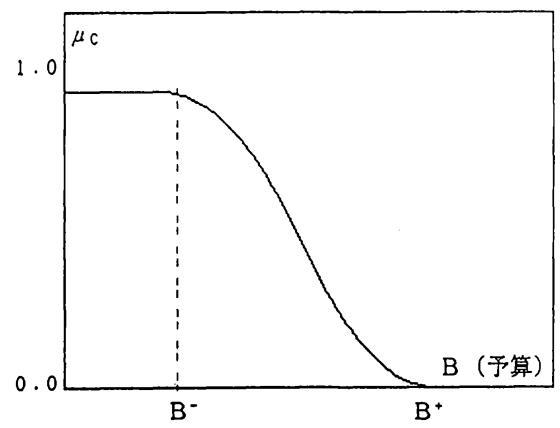

図一6 $\quad \boldsymbol{Z}$ 関数による費用制約条件

表一3 ファジィ増分便益費用分析の計算結果

\begin{tabular}{|c|c|c|c|c|c|c|}
\hline 予算制約 & 8000 & 9000 & 10000 & 11000 & 12000 & 13000 \\
\hline 線形制約 & \multicolumn{4}{|c|}{$\begin{array}{l}81600 \\
(7892)\end{array}$} & $\begin{array}{l}91020 \\
(8912)\end{array}$ & $\begin{array}{l}97110 \\
(9352)\end{array}$ \\
\hline $\begin{array}{c}Z \text { 関数 } \\
\text { 制 }\end{array}$ & $\begin{array}{l}81600 \\
(7892)\end{array}$ & & $\begin{array}{l}00 \\
52)\end{array}$ & $\begin{array}{l}91020 \\
(8912)\end{array}$ & $\begin{array}{l}97110 \\
(9352)\end{array}$ & $\begin{array}{l}104410 \\
(10112)\end{array}$ \\
\hline
\end{tabular}

総便益（総費用）

ても線形関数に比べて大きい予算額を設定することにな るので, 式 (13), 式 (14) を参照すれば便益（ $Z_{f}$ の值 の増加), 費用 $\left(b\right.$ が $B^{+}$に近づく) ともに前者より大 きな値となることがわかる.

このような定式化を行った場合には, 以下のような点 が解の決定に関与することになる。

(1)この問題の定式化において, 制約条件の最大值は 結局, 各変数の許容される変化分を示すことになる。こ れは結局, 目的関数メンバシップ值の最大可能範囲を決 定していることになる.したがって $B^{+}$の值が増加すれ ば，当然目的関数の変化上限 $\left(Z^{*}(x)\right)$ が大きくなり, この問題より得られる最終決定の満足度は小さくなる (つまりメンバシップ関数の変化は緩慢になり, 関数值 の小さい䇢所で均衡する).

(2) 制約条件の上限 $B^{+}$值の変化は, メンバシップ関 数の傾斜 (変化の勾配) を変更していることになる.し たがってこの值を増加させると傾きは緩やかになり，こ れに伴い, 得られる組合せ解の変化も緩慢になる.
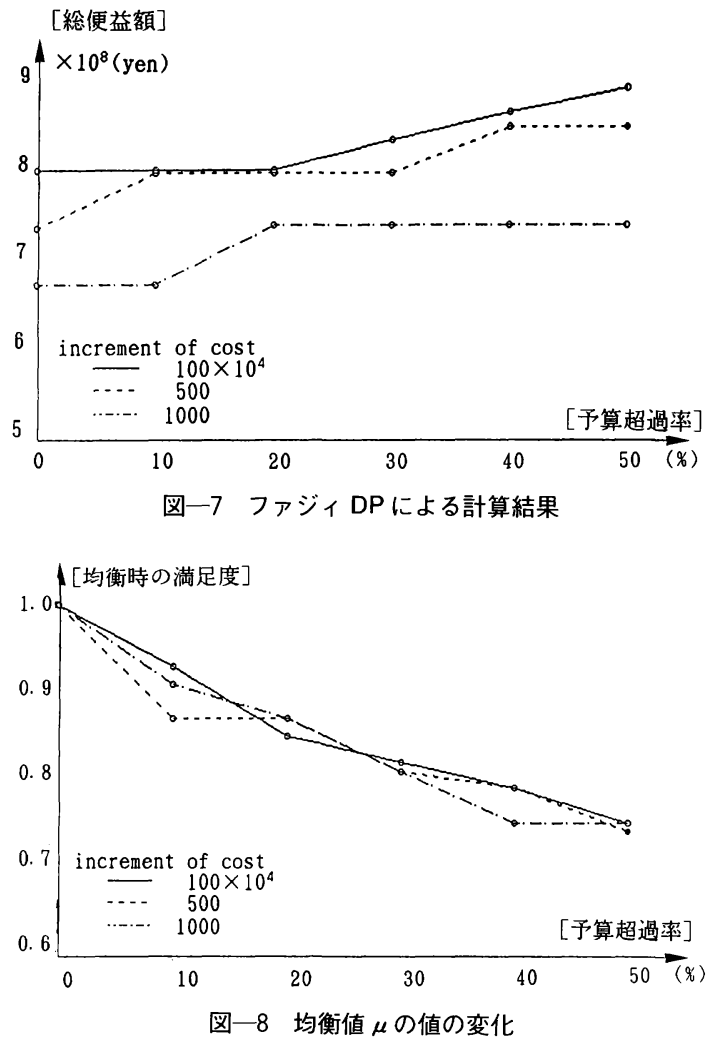

（3）ファジィ制約をもつ動的計画法

a) ファジィ制約をもつ動的計画の解法

すでに述べたように，ファジィ数理計画法は従来の数 理計画問題に一般的に用いることができる.したがって 「増分便益費用分析」の拡張に利用したアルゴリズムは， ファジイ予算制約をもつ動的計画問題を取り扱う場合も 同様に用いることができる，したがって，ファジィ意思 決定としての解法上は全く変わる点はない。

しかし動的計画法においては,「増分単位費用」と併 せた検討が定式化の性質上重要である。この点から得ら れる解の特徵をみるために, 予算の制約に対するメンバ シップ関数は線形の場合を考え検討を行った。

b) 計算結果之その検討

ここでは解の変化傾向をみるために, 増分単位費用を 100 万円, 500 万円, 1000 万円の 3 ケースとし, またファ ジィ制約の最大值 $\left(B^{+}\right)$を初期予算額の $10 \%$ ～ $00 \%$ ま での $10 \%$ ごとに変化させて, ファジィDP 問題を解い た. それぞれの計算結果から得られる総便益と均衡下の メンバシップ関数值 $\mu$ を図示したものが図一7および図 -8である. 図一7から単位費用增加分が大きくなると, 従来の非ファジィ動的計画問題自体が鈍感な解の変化し か与えなくなるので, ファジィ制約条件の示す予算余裕 分に対しても敏感ではなくなる，たとえば，1000万円 
を単位とする計画では，20％以上のファジィ性導入効 果は現われていないことがわかる.

また，図一8より均衡下の満足度を示す $\mu$ の值は，い ずれの場合も制約条件の幅が大きくなると（制約条件の メンバシップ関数の傾きが小さくなるので）徐々に均衡 值は小さい（満足程度の小さい）対策案が抽出されるこ とになる，また，当然のことではあるが，予算超過率 $\left(\left[B^{+}-B^{-}\right] / B^{-}\right)$が $0 \%$ のときには, 従前のクリスプ問 題と一致し, 均衡時の満足度 $\left(\mu_{D}\left(x^{*}\right)\right)$ はいずれの場合 にも 1.0 となる.

c）ファジィ制約とその意義

前項では増分便益費用分析，ここではDPによる方 法について，おのおのファジィ予算制約を付加するため の手順を述べた.

このように従来の方法を用いて解決される各種の問題 にファジィな制約条件を用いることは，最も典型的な ファジィ性考慮の方法である。したがって，これは一般 に費用に関する余裕を考えたものである. 都市高速道路 のような施設の場合には交通安全対策に関する費用だけ で予算が計上されることは少なく，通常維持管理費用に 含まれ，安全対策が必要なときに用いることができるも のとなっている場合も多くみられる. したがって㛜密に 維持管理費用全体の何％を占めるかをあらかじめ決定 していくことは難しい. ファジィな数として決定される 之考えることは現実的である ${ }^{91}$.

また仮に，交通安全対策費用として一定の予算が計上 されている場合においても, 従来の方法では, 若干の予 算の超過も許すことのない意思決定がなされることにな り，適切な代替案を選択しているかどうかは疑わしい.

これは, 計画問題の頑健性 (robustness) を考慮する ものである.したがってあらかじめ計画における余裕(本 研究の場合予算に関するもの）を考えて，この中ででき るかぎり満足されるものを採用するということである.

\section{4. ファジィ便益を用いた整数計画法}

\section{（1）ファジィ便益についての検討}

これまでは，予算の制約におけるファジィ性を考えた が, 次に予測される便益のファジィ性について検討する. 本研究のような問題で各対策により予測される便益は実 際には，あらかじめ厳密に算定しておくことは難しく， これをクリスプ数として決定的に定義するよりもある程 度の幅をもったファジィ数として表現することが実用的 であると考えられる.

具体的には整数計画における定式化のうち，便益に関 するパラメーターをファジィ量として取り扱った．さき に定式化されたもののうち係数 $b$ で示される便益項に ついて検討したものである.
ここでは, 安全施設の設置便益におけるファジィ性を 考慮するための例として, 各対策案の中でも直接効果の 観測しにくいと思われる「クッションドラムの設置」に 着目した. すなわち表一1の対策案集合において，クッ ションドラムの設置を個別対策の中に含むものを対象と している.ここで最終的な便益に影響を与える大きさは, 「クッションドラム設置費用」の対策案全体に占める割 合を用いた。たとえばII -1 においてはクッションドラ 厶設置費用 260 万円 $\left(=\mathrm{D}_{2} \times 20\right)$ であることから，18\% (=260/1 420) のファジィ性を導入している.

このときのファジィ便益パラメーター $b_{f}$ は, 簡単の ために, 区間 $[b-0.18 \cdot b, b+0.18 \cdot b]$ にある三角型ファ ジィ数 (Trianglar Fuzzy Number) であるとする11!.

同様にして, 関連する各便益パラメーターのファジィ 化を行った. 本研究の問題では, 総便益に関連したパラ メーターは 19 個で構成されているが, このうち 11 個が ファジィパラメーターとなった.

\section{(2) 計算結果とその考察}

本問題の計算は, 最終的にファジィ集合に関する「拡 張原理」を用いて演算を行うことができる. 実際には式 （12）に示すように， $\alpha$ カット集合を用いることで容易

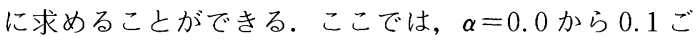
とに $\alpha=1.0$ までの計算を行った.

この例では個々の対策実施時の予測便益額がファジィ 数で与えられるので, 当然最終的な計算結果の便益も ファジィ数で得られる.この計算結果を図示したものが 図一9である。

この結果から, まずファジイ総便益の可能性分布を知 ることができる.この場合は $\alpha$ カット集合ごとに計算 が実行されるので，必ずしも最終的な対策案の組合せが 一意ではなく， $\alpha$-レベルごとに異なってくる．したがっ て最終的な分布は非線形なものとなっている.

またこうした分布を利用する場合に，これを期待され る総便益の可能性の範囲として利用できる.これは従来 㛜密に設定することが難しい便益額をファジィ数として 設定しても，ある程度の判断が可能であることを示して いる. また計算結果として, 一意的な值とすることが必

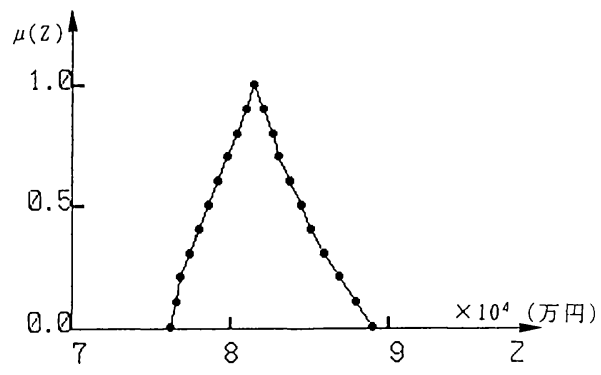

図一9 ファジィ数を用いた総便益額の表現 
要である場合には，非ファジィ化 (defuzzification) の 操作をすることによって代表值を求めることができ る ${ }^{11}$. 一般によく用いられる重心による方法を用いれば, この場合は, $Z=81850$ となりメンバシップ值 1 の点と ほぼ同一になっていることがわかる。

このようにファジィ理論を用いた方法論の拡張によ り, 従来の算出結果を包含した形の計画案検討が可能と なる。

\section{5. おわりに}

本研究は都市高速道路における交通事故安全対策の策 定方法に関して, 従来の数理計画的方法にファジィ理論 を用いた展開の方法について検討した。

まず都市高速道路での交通安全対策の策定手順につい て, 数理計画的な解法について, 3 種類の方法を紹介し その方法論の特徵を比較して検討した。最適解を求める 点では各方法とも同様であるが，定式化と分析可能な項 目での相違が明らかになった．さらにこれらの検討結果 に基づき，各方法へのファジィ性導入方法を行った．具 体的には計画におけるファジィネスとして予算の余裕, 予測便益に対する判断の幅についての計算方法を示すと ともに例題による検討を行った，以上の上うな手順によ り得られた研究成果として以下の点が挙げられる.

（1）都市高速道路において, 交通事故の発生は人身, 物損はもとより，高速道路の使命である高速性も阻害さ れることになり安全対策の合理的作成方法の検討は重要 である。この場合，詳細で厳密な計画案の導出方法が確 立されていない現状では，規範的手順で得られた解を頑 健性を含んだ形で利用する必要がある．この点で，計画 の余裕を考慮したファジィ性の導入は重要である。

（2）交通事故多発地点が都市高速道路では明確であ ること，路線ごとに分離して検討が可能であることなど の理由加「予算制約内の個別代替案の組合せ」として 定式化が可能でありいくつかの解法が考えられる。これ らはその解の撖密性，立案作業の容易性などからそれぞ れの方法の特徵を生かしながら，ファジィ性を考慮する ことが可能である。

（３）代替案作成計画においてファジイ理論を導入す ることは, 従来のクリスプな計画立案を含んだ形での拡 張となっており，この可能性分布の有効な利用を考える ことで, 計画上有益な情報を与えるものとなり得る. 特 に本研究で示したファジィ制約の利用と，便益のファ ジィ数表現はその最も典型的な方法として各種検討の基 礎となり得る。

最後に本研究で提案した方法をさらに実用的なもの之 し，またさらに有効で現実的な交通安全対策案を導くた めに検討すべき今後の課題を述べる.
（1）本研究では代替案の評価プロセスにおいて，交 通安全対策に対する各側面からの評価を試みているが, 評価項目の決定についての十分な検討が行われていな い. 特に利用者の快適性や対策案の実行可能性について の十分な検討が望まれる．この点についてもファジィネ スに対する考慮が可能である。

（2）ここでは，交通安全対策として施設整備などの 物理的施策について述べたが，実際には注意喚起のため の広報的活動，円滑交通実現のための情報伝達など副次 的対策とそのファジィ性については言及していない。本 研究で述べたような安全対策もこうした各種施策との総 合的な取扱いの中で初めて効率的である。したがって各 施策を含んだ体系的検討も必要である。

（３）計画においてファジィ決定を行うことは，意思 決定における余裕あるいは頑健性を考慮していることに なる．定式化を行ううえでファジィな取扱いが可能であ るのは，必ずしも制約条件だけではなく，この点その他 の定式化とその意義は検討する必要がある.

謝 辞：本研究を終えるにあたって，関連資料の収 集に関して，阪神高速道路公団大阪管理部に感謝の意を 表する次第である.

\section{参 考 文 献}

1）総務庁編：平成元年版交通安全白書, 大蔵省印刷局, 1989.

2) National Technical Information Service : Assesment of Techniques for Cost-effectiveness of Highway Accident Countermeasures, 1979.

3）阪神高速道路公団：阪神高速道路のしごと，1988

4) 秋山孝正：交通事故安全対策の系統的策定方法について の研究, 交通安全対策振興助成研究報告書, Vol. 3, pp. 7 16, （財）佐川交通社会財団， 1988 .

5）秋山孝正・佐佐木綱：都市高速道路交通安全対策案作成 方法についての比較研究, 土木計画学研究・講演集, No. 11, pp. 275 282, 1988 .

6）秋山孝正・邵 春福・佐佐木綱：都市高速道路における 交通安全対策の作成方法についての方法論的考察，交通 工学, Vol. 25, No. 6, pp.9〜19, 1990.

7) 坂和正敏：線形システムの最適化, 森北出版, 1984

8) 浅居・ネゴイタ：ファジィシステム理論入門, 第 8 章, オーム社, 1987

9）秋山孝正：高速道路交通計画におけるファジィ理論と知 識工学手法の応用に関する研究，京都大学学位論文，第 6 章, 1989.

10) Takamasa Akiyama and Takashi Uchida : Traffic Safety Planning : Incremental Benefit-Cost Analysis with Fuzzy Budget Constraints, International Workshop on Fuzzy System Applications, pp. 161 162, 1988.

11）本多中二・大里有生：ファジィ工学入門，海文堂，1989

(1990.1.23 • 受付) 